\title{
THE ENFORCEMENT PROVISIONS OF THE FOOD, DRUG, AND COSMETIC ACT
}

\author{
Frederic P. LeE*
}

As federal regulatory legislation goes, the Food and Drugs Act of $1906^{1}$ has left in its wake an extensive administrative and judicial history. This has made available much experience as to the effectiveness of the rather wide variety of enforcement procedures that the Act embodies. The new Federal Food, Drug, and Cosmetic Act of $193^{2}$ which becomes effective June 25 th, next, perfects and supplements these procedures in the light of such experience. ${ }^{3}$

The Basic Procedures. The Act of 1906 provided three basic judicial and administrative procedures for the enforcement of its prohibitions against the shipment in interstate or foreign commerce of adulterated or misbranded foods. These procedures were: (r) judicial criminal proceedings with fine or imprisonment as the penalty; (2) judicial libel for condemnation proceedings with forfeiture and either destruction, disposition by relabeling or reconditioning, or sale of the articles as the penalty; (3) administrative exclusion of imports proceedings with either destruction, exclusion from domestic commerce, or relabeling or reconditioning as the penalty. By later. amendment to the Act of 1906 there was also provided (4) an administrative inspection proceeding covering seafoods. ${ }^{4}$

The foregoing enforcement procedures are retained by the new Food, Drug, and Cosmetic Act of 1938 , and the first three of them are made applicable to cosmetics

- Ph.B., 1915, Hamilton College, A.M., 1917, L.L.B., 1918, Columbia University. Member of New York, District of Columbia, and U. S. Supreme Court Bars. Member of law firm of Alvord and Alvord, Washington, D. C. Assistant Legislative Counsel, U. S. House of Representatives, 19r9-22; Legislative Counsel, U. S. Senate, 1922-30; Special Counsel to Secretary of Agriculture, 1933; Member and General Counsel, Federal Alcohol Control Board, 1934-35; Professor of Statute Law, Georgetown University Law School, $1929-35$.

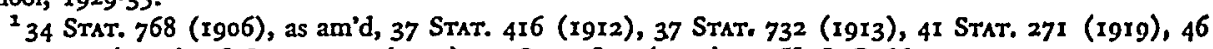
Stat. roig (1930), 48 Stat. 1204 (I934), 49 Stat. 87 I (1935), 21 U. S. C. 5\$I-I5.

${ }^{2}$ Pub. No. 717, 75th Cong., 3d. Sess., approved June 25, 1938, 52 STAT. 1040, 21 U. S. C. A. c. 9 (Supp. 1938). (In citations to U.S. Code sections hereinafter, reference to this Supplement will be omitted.)

${ }^{8}$ One or more of these procedures are common to the Tea Import Act of 1897,29 STAт. 604, 21 U. S. C. c. 2, the Meat Inspection Act, 34 STAT. 674, 2 I U. S. C. $\$ 57$ I-96, the Insecticide Act of 19ro, 36 STAT. 335,7 U. S. C. c. 6 , the Naval Stores Act of 19ro, 42 StAT. 1435, 7 U. S. C. c. 4 , the Federal Import Milk Act of I927, 44 STAт. IIOI, 2I U. S. C. \$\$I4I-I49, and the Federal Caustic Poison Act of 1927, 44 STAT. $x_{406,15}$ U. S. C. c. II. The Food and Drugs legislation together with these companion acts constitutes a distinct group from the viewpoint of the development of federal administrative law. Much of the discussion here of the enforcement procedures of the new Act of 1938 could readily be applied to other members of this statutory family.

48 Stat. I204 (1934), as am'd, 49 Stat. 87 I (1935), 2 I U. S. C. $\$ 372 a$. 
and therapeutic devices as well as foods and drugs. Further, the new Act contains a permit system applicable to any class of food that may, by reason of contamination with micro-organisms during its manufacture, processing, or packing, be injurious to health, provided the injurious nature cannot be adequately determined after entrance of the food in interstate commerce. The new Act also provides a special permit system requiring a manufacturer of any new drug to secure an order of the Secretary of Agriculture making effective the manufacturer's application for permission to introduce the drug into interstate commerce. The Secretary's order must be based on findings that the drug is safe for use under the conditions proposed to be prescribed for its use in its labeling. 5 Further, the new Act adds a new court proceeding for injunctive relief at the instance of the government to restrain certain violations of the Act. Finally, to facilitate the policing activities of the Food and Drug Administration, statutory authorization is given by the new Act for the inspection of factories, warehouses, and other establishments, ${ }^{6}$ and for the copying of carriers' records showing interstate shipment of food, drugs, or cosmetics and also the records of persons holding such goods after shipment. ${ }^{7}$

\section{Collection of Samples}

Sampling and analysis is a prerequisite in practically all instances to instituting any of the above proceedings. The procedure for sampling and the limitations thereon, mostly constitutional in character, are of importance to both the government and the individual.

Under the old Act the power to make regulations for collection and examination of samples was specifically provided. The new Act makes no such affirmative grant of power but apparently relies on a more general authority conferred ${ }^{8}$ to conduct examinations and investigations through officers and employees of the Department of Agriculture or through state health, food or drug officers or employees duly commissioned by the Secretary of Agriculture as officers of the Department. The Act then continues" "where a sample of a food, drug or cosmetic is collected for analysis under this Act" the Secretary shall, upon request, provide a part of the official sample for examination or analysis by the owner or any person named on the label of the article. The statute thereby recognizes the collection and analysis of samples as one form of examination and investigation and at the same time makes mandatory the duty of apportioning the official sample-a duty previously recognized only in regulations. However, the statute permits this right to a portion of the official sample to be restricted by reasonable exceptions and terms and conditions to be prescribed by the Secretary. $0^{\text {a }}$

\footnotetext{
${ }^{5}$ For further discussion of this provision, which is not treated in this article, see Cavers, The Food, Drug and Cosmetic Act of 1938: Its Legislative History and its Substantive Provisions, supra at p. 40, and Hoge, An Appraisal of the New Drug and Cosmetic Legislation from the Viewpoint of Those Industries, infra at pp. xrg-I20.

$\$ 704,21$ U. S. C. 5374 .

$\$$ \$702(a), 21 U. S. C. $\$ 372(a)$.

T5703; 21 U. S. C. 5373.

\$702(b), 2 I U. S. C. 5372 (b).

See Regulations for the Enforcement of the Food, Drug, and Cosmetic Act, 3 FED. REG. 3I6r, 3170 (Dec. 28, 1938).
} 
The Sampling Procedures. There are several classes of samples obtained as a result of several sampling procedures: (I) samples obtained through purchases in the open market from wholesalers and retailers; (2) "voluntary" samples furnished by the manufacturer; (3) samples furnished by state health, food or drug officials or obtained pursuant to "state embargoes" imposed by such officials; (4) samples obtained through libel for condemnation proceedings; (5) samples obtained while imported goods are held in customs custody pending determination of admissibility; (6) samples obtained from a producer of goods subject to a permit system, provision for the taking of such samples being a condition of the permit.

Only the third and fourth classes of samples listed above call for discussion. Recourse to state officials is important where samples neither can be purchased in the market nor are furnished by the manufacturer, because the Fourth Amendment, prohibiting unreasonable searches and seizures, denies to federal officials power to take goods without a search warrant, ${ }^{10}$ and, under federal statutes, search warrants can be obtained only if the property to be seized is used in the commission of a felony. ${ }^{11}$ Violations of the Food, Drug, and Cosmetic Act are misdemeanors and not felonies. ${ }^{12}$

The Fourth Amendment, however, is applicable to state officials only when they are acting primarily in a federal capacity. ${ }^{13}$ Samples taken by them primarily for the enforcement of a state act are not subject to the Amendment and may be admitted as evidence in a proceeding under the Federal $\mathrm{Act}^{14}$ even where the applicable state constitutional or statutory requirements are not complied with..$^{15}$ In some states, moreover, state officials are permitted to "embargo," i.e., seize and hold in custody, pending examination, articles suspected of being adulterated and misbranded, ${ }^{10}$ and articles so seized become accessible to federal officials for sampling purposes.

In libel for condemnation proceedings following the filing of the libel the article in question is seized by judicial process and thereby comes within the jurisdiction of

${ }^{10}$ Grau v. U. S., 287 U. S. 124 (I932); Sgro v. U. S., 287 U. S. 206 (I932); Nathanson v. U. S., 290 U. S. 4 I (r933).

ii There are a few exceptions not relevant here.

$12 \$ 303($ a), 21 U. S. C. $\$ 333($ a). See p. 77 , infra.

${ }^{25}$ Cf. Gambino v. U. S., 275 U. S. 3 10 (1927). See $\$ 702(a), 21$ U. S. C. $\$ 372(a)$, for authority to commission state officials as federal agents.

1s Gambino v. U. S., supra note 13. Thus if articles are obtained by the state officials for immediate use in their state How enforcement activities and are only subsequently turned over to the federal authorities, then the articles are admissible as evidence in federal proceedings. Center v. U. S., 267 U. S. 575 (I925); Schroeder v. U. S., 7 F. (2d) 60 (C. C. A. 2d, 1925). On the other hand, articles are inadmissible as evidence in federal proceedings if the search and seizure is made by the state officials under the direction of federal officials, or in their presence, or solely for the purpose of aiding the United States in the enforcement of its laws. Flagg v. U. S., 233 Fed. $48 \mathrm{I}$ (C. C. A. 2d, rgI6) approved in Silverthorne Lumber Co. v. U. S., 25 I U. S. 385 (1920); Byars v. U. S., 273 U. S. 28 (1927); Gambino v. U. S., supra. In this last case the articles seized were.turned over to the federal officials although they were not present at the search and seizure and the state officials did not act under their direction. See also the following cases in the U. S. District Court for the Western District of New York: U. S. v. Bush, 269 Fed. 455 (1920); In re Schuetz, 299 Fed. 827 (1924); U. S. v. Rossi, I2 F. (2d) 956 (1926); U. S. v. Costanzo, I2 F. (2d) $259(1926)$.

IT U. S. v. Capon Water Co., 30 F. (2d) 300 (E. D. Pa. 1929).

${ }^{16}$ Illinois, for example, has an "embargo" statute of this character. ILr. Stat. ANN. (Callaghan, 1924) c. $56 \mathrm{~b}$, par. 30 . 
the court. Either the United States or the claimant may then move that the court allow through judicial process, the taking of samples of the seized article for the purpose of analysis and test. Such motions were usually granted under the old Act. ${ }^{17}$ The new Act, ${ }^{18}$ however, makes it the duty of the court to allow parties representative samples, and in the case of fresh fruits and fresh vegetables, also to require that there be furnished the claimant a copy of the government analysis that served as a basis for instituting the proceeding and of the identifying marks of the packages from which the government prior to the seizure obtained the samples analyzed.

Analyses. The new Act lays down no requirements as to analyses. In the past these have been prescribed by regulations. Usually they are those recognized in the United States Pharmacopoeia or National Formulary, or those prescribed by the Association of Official Agricultural Chemists. If no method has been so recognized or prescribed, then methods satisfactory to the Secretary of Agriculture are used. The validity of the tests used may, of course, be questioned in any enforcement proceeding in the courts.

\section{Institution of Court Proceedings and Preliminary Hearing}

Preliminary Administrative Action and Hearing in Criminal Cases. Under existing administrative practice a field inspector, in case of interstate shipments, forwards for analysis to the proper field station of the Food and Drug Administration all samples collected and suspected of being in violation of the Act. The results of the analysis are sent by the station chief with his recommendations to the chief of the district. If the district chief approves the recommendations and a criminal prosecution is contemplated, he instructs the station chief to cite the manufacturer and shipper of the product and other interested parties to appear at a hearing at the station's headquarters to present evidence and show cause why the matter should not be referred to the Department of Justice for prosecution. A record of the hearing and usually a transcript of the evidence is kept. The respondent is given full opportunity to explain the situation. Rules of evidence are not followed.

The station chief determines whether, as a result of the hearing, the case should be placed in permanent abeyance or proceeded with further. In making this determination consideration is given to such factors as seriousness of the violation, whether the respondent has since the citation changed his product to conform with the law, whether the violation was malicious or unintentional, whether it is a first offense, and, in general, whether the respondent has displayed a willingness to abide

\footnotetext{
${ }^{17}$ In U. S. v. B. \& M. External Remedy Co., 36 F. (2d) 53 (S. D. N. Y. 1929), the obtaining of samples pursuant to libel proceedings was held not to constitute unreasonable search or seizure or compulsory self-incrimination in violation of the Fourth and Fifth Amendments. The court did, however, condition its ruling by requiring the government to pay to the owner the value of the samples taken in case it was not successful in having the goods condemned. The court also imposed the following condition: "Further, I think it proper to require that the claimant be given samples from the same containers and that it be permitted to be present at all the tests." This last condition made the samples of little value to the government for the presence of the claimant at the tests would result in the government's having to disclose to him prior to trial the nature of its evidence.

${ }^{18} \S_{304}(\mathrm{c}), 21$ U..S. C. $\$ 334(\mathrm{c})$.
} 
by the law. The recommendation of the station chief is usually followed, reversals resulting from administrative policies rather than from a different view of the facts. The informality of the hearing makes it possible for the record to include any argument on facts or law even though it might tend to defeat the successful prosecution of the case. Conversely, however, damaging admissions are frequently made by respondents and, while the statements are not under oath, their repudiation in a subsequent trial may be embarrassing.

A summary of the findings together with the recommendations are forwarded to the district chief who may endorse the recommendations as they stand or modify them. The record is then sent to the chief of the Food and Drug Administration in Washington, where, if it is decided to prosecute, the matter is referred to the Solicitor of the Department of Agriculture as to the sufficiency of the evidence. Thereafter, the case is transmitted by authority of the Secretary of Agriculture to the Department of Justice for final transmission to the United States Attorney for the proper judicial district.

The new Act specifically provides ${ }^{19}$ that before any violation is reported by the Secretary of Agriculture to any United States Attorney for the institution of a criminal proceeding the person against whom the proceeding is contemplated shall be given appropriate notice and opportunity to present his views, either orally or in writing, with regard to the contemplated proceeding. By regulation the Secretary has provided that the "presentation of views ... shall be private and informal." The old Act also provided for such a hearing although the language was ambiguous and was construed by some courts as requiring administrative hearings preliminary to libel for condemnation, as well as criminal, proceedings. ${ }^{20}$ Further, the new Act adopts the administrative construction previously placed on the old Act that the prospective defendant is entitled to a hearing and not merely the person, such as a bailee, wholesaler, or retailer, from whom the sample is obtained.

Under the old Act the United States Attorney had the duty of instituting criminal proceedings upon report of any violation by the Secretary of Agriculture. He was bound to accept the findings of the Secretary and not make any other independent investigation to satisfy himself. However, the United States Attorney could also under other general provisions of law, on his own initiative, institute proceedings irrespective of receipt of any report by the Secretary of a violation. In such event the statute required no preliminary administrative hearing. ${ }^{21}$ The new Act omits the mandatory duty of the United States Attorney to prosecute at the Secretary's direction. In consequence the District Attorney has discretion in all instances as to whether criminal proceedings will be instituted. The right to a preliminary administrative hearing still exists only when the Secretary reports the violation and does not

\footnotetext{
${ }^{10} \$ 305,21$ U. S. C. $\$ 335$. For the new regulations on this section, sec 3 Fed. REg. 316r, 3162 (Dec. $28,1938)$.

${ }^{20}$ See, e.g., U. S. v. 74 Cases of Grape Juice, I8I Fed. 629 (W. D. N. Y. Igro); affd, U. S. v. 20 Cases of Grape Juice, 189 Fed. 331 (C. C. A. 2d, 191 I).

${ }^{21}$ U. S. v. Morgan, 222 U. S. 274 (rgrr).
} 
exist when prosecution is instituted by the United States Attorney on his own initiative. Nevertheless the administrative hearing constitutes a real protection against unfounded criminal prosecutions in food and drugs cases for it is only rarely that the United States Attorney institutes such prosecutions otherwise than at the instance of the Secretary.

According to the Supreme Court, the administrative hearing is not judicial in character. The parties are not compelled to attend. Any party who does attend is not in jeopardy, for an adverse finding is not binding against him in any way, but is merely a preliminary determination. A decision in his favor is not an acquittal in the sense that it prevents a subsequent hearing before the Department or prevents court proceedings being instituted. ${ }^{22}$

Preliminary Administrative Action in Libel Cases. The preliminary administrative procedure in libel for condemnation cases has been similar to that in the criminal cases except that, as pointed out above, there is no administrative hearing held prior to the institution of the libel for condemnation proceedings. Also, the Solicitor of the Department communicates directly with the United States Attorney rather than through the Department of Justice.

Where even greater speed is necessary, the so-called "direct seizure" procedure is followed by the Food and Drug Administration. Under this procedure the field station communicates directly with the United States Attorney for the judicial district and no prior consideration is given by the district chief or by the Food and Drug Administration in Washington to the particular contemplated action. The direct seizure procedure is used where the article is one that rapidly deteriorates or that is expected to be moved into consumption before the necessary steps could be taken by way of the Food and Drug Administration in Washington. Such direct seizures, however, are made only pursuant to definite policies predetermined by the Food and Drug Administration and sanctioned by the Department of Justice.

Discretion in Institution of Proceedings. Under the administrative practice pursuant to the old Act, libel for condemnation proceedings are instituted in only four classes of violations: $(r)$ food products containing added poisonous or other added deleterious ingredients which may be harmful to health; (2) food products consisting in whole or in part of filthy, decomposed, or putrid animal or vegetable substances, or any portion of an animal unfit for food, or a product of a diseased animal, or one that has died otherwise than by slaughter; (3) food or drug products so grossly adulterated or misbranded with false or fraudulent claims that their distribution constitutes a serious imposition upon the public; and (4) deliberate frauds in the shipment of adulterated and misbranded food products that seriously demoralize legitimate trade practices. Unless a violation falls clearly within one of these four classes, seizure action is usually not taken, but the party responsible for the violation is prosecuted criminally. If the violation falls within one of these four classes and is of a deliberate character both types of action may be taken. There is nothing in

nlbid. 
the provisions of the new Act that necessitates a change in the above administrative practice.

Leaving aside the question of "multiple seizures," the exercise of discretion by the federal authorities in determining whether to institute criminal or libel for condemnation proceedings or both is not subject to judicial interference. ${ }^{23}$ Further the new Act ${ }^{24}$ makes specific provision that the Secretary of Agriculture need not report minor violations for the institution of criminal, libel for condemnation, or injunction proceedings if he believes the public interest will be adequately served by a suitable written notice of warning. This provision gives legislative sanction to the exercise of discretion in instituting proceedings to the end of avoiding trivial or unnecessary litigation. ${ }^{25}$

\section{Crimtnal Proceedings}

Prohibited Acts. The principal prohibitions of the new Act to which criminal and injunction proceedings apply, are the introduction or delivery for introduction into interstate commerce of any food, drug, device, or cosmetic that is adulterated or misbranded; the adulteration or misbranding of any such article in such commerce; and the receipt in such commerce of any article plus the delivery or proffered delivery thereof for pay or otherwise, except that the recipient may relieve himself of penalties if the delivery or proffer is made in good faith and on request he furnishes the government with the name and address of the person from whom he purchased or received the article and copies of all documents pertaining to the delivery. There is also prohibited the introduction or delivery for introduction into such commerce of an article if such article is required to be manufactured, processed or packed under the permit system and no such permit is in force, or such article is a new drug and no application for its use has become effective. A shipper's guarantee that the article is not adulterated or misbranded, or was manufactured, processed, or packed under permit if so required, will also relieve a recipient from penalties for the above basic violations.

Other less important prohibitions relate to refusal to permit entry and inspection of factories; copying of records relating to interstate movement of articles; false guarantees; simulating government marks and other identification devices; revealing of trade secrets by government officers and employees; alteration, mutilation, destruction, obliteration, or removal'of any label if done while the article is held for sale after interstate shipment ${ }^{26}$ and it results in the article being misbranded under

See, as to libel for condemnation cases, Shawnee Milling Co. v. Temple, I79 Fed. 517 (S. D. Iowa 19ro); National Remedy Co. v. Hyde, Not. Judg., Food \& Drugs, No. I6780 (Sup. Ct. D. C. x929).

$\$ 306,21$ U. S, C. $\$ 336$.

${ }^{25}$ H. R. REP. No. 2139, 75th Cong., 3d Sess. (1938) 5.

* Removal and Alteration of Labels. - To facilitate detection subsequent to interstate shipment of misbranding violations and preserve evidence of such violations, it is necessary that labels on the articles at the time of interstate shipment shall not be altered or removed prior to the time that the articles reach the ultimate consumer. This means that the federal regulatory power must protect the articles in situations that ordinarily would be considered as involving intra-state commerce. It also means that conflicting state requirements that would necessitate alteration or removal of the federal labels following completion of interstate shipment, must be held invalid. Appreciating the practical exigencies of such situations the 
the Act; and specification on the labeling or in any advertising that ąn application with respect to the use of a new drug has been approved by the Secretary. The injunction proceedings are also available to restrain the two minor violations last mentioned.

Penalties. Under the old Act a violation was subject to a fine of not exceeding $\$ 200$ for the first offense, and for each subsequent offense to a fine of not exceeding $\$ 300$ or imprisonment not exceeding one year or both. ${ }^{27}$ The usual penalty imposed was a small fine. Even for subsequent offenses the imprisonment penalty was rarely imposed. Because of the smallness of the fines the payment of them amounted to a small license fee for doing the illegal business. During the fiscal year 1937 fines in any one case covering one or more violations varied, according to the chief of the Food and Drug Adninistration, from sums as low as $\$ 1, \$ 2$ and $\$ 5$ to a maximum actually paid of $\$ 1,500.00$. Higher fines were imposed in several cases but were remitted in large part by the courts. Three small sentences imposed in connection with second offenses were also suspended and the defendants placed on probation. Under the new Act a first offense without intent to defraud or mislead subjects the violator to a fine of not more than $\$ 1,000$ or imprisonment of not more than one year or both, but a second or subsequent offense and a first offense with intent to defraud or mislead are punishable by a fine of not more than $\$ 10,000$ or imprisonment for not more than three years or both. By reason of specific statutory provision all offenses under the Act remain misdemeanors despite the provisions of the Act of December $x 6,1930,{ }^{28}$ which define a felony as an offense punishable by death or imprisonment for a term exceeding one year and a misdemeanor as all other offenses.

Petty Offenses and Jury Trial. The Sixth Amendment to the Constitution

courts have held that while the states may impose restrictions or require information in addition to what is required by the federal government, Savage v. Jones, 225 U. S. 50 I (Igr2); Armour \& Co. v. North Dakota, 240 U. S. 510 (Ig16); Crescent Mfg. Co. v. Wilson, 233 Fed. 282 (N. D. N. Y. 1916); Fougera v. City of New York, 224 N. Y. 269 , 120 N. E. 642 (I9r8); Day Borgwall Co. v. State, I90 Wis. 8, 207 N. W. 959 (1926); Royal Baking Powder Co. v. Emerson, 270 Fed. 429 (C. C. A. 8th, 1920), even where the article remains in the original package up to the time of retail sale, Savage v. Jones, supra, Standard Stock Food Co. v. Wright, 225 U. S. 540 (Igr2); Corn Products Refining Co. v. Eddy, 249 U. S. 427 (1919), nevertheless, where the state requirements interfere or conflict with those of the federal government, they are invalid. Thus a state statute has been declared invalid that required the removal of a label conforming to federal law and the substitution of a label conforming to state law. McDermott v. Wisconsin, 228 U. S. 115 (1913); of. Weigle v. Curtice Bros., 248 U. S. 285 (1919). The above prohibition in the new Food, Drug and Cosmeric Act relating to the alteration and removal of labels would seem to write into that Act the rule enunciated in the foregoing cases. The Caustic Poison Act of $x 927$, supra note 3 , contains a provision with respect to alteration or removal of labels similar to that in the new Act, but no litigation has arisen with regard thereto. Cf. as to Meat Inspection Act, U. S. v. Lewis, 235 U. S. 282 (1914), and U. S. v. Green, 137 Fed. I79 (N. D. N. Y. I905).

${ }^{n}$ If different kinds of articles are included in one shipment, and each kind is in violation of law, separate penalties can be imposed. U. S. v. Direct Sales Co., 252 Fed. 882 (W. D. N. Y. I9r8). This cannot be done, however, if the shipment consists of several packages but all of the same kind of article. U. S. v. Watson-Durand-Kasper Grocery Co., 251 Fed. 310 (D. Kan. I9I7). Charges of both misbranding and adulteration for the same act, permissible in some cases, serve to increase the amount of the penalty that may be imposed. See, e.g., U. S. v. Tilden Co., Not. Judg., Food \& Drugs, No. 17325 (S. D. N. Y. I93I).

${ }_{46}^{6}$ Star. 1029. See U. S. v. Chapman, 3 F. Supp. 900 (S. D. Ala. I93I); U. S. v. Venturini, I F. Supp. 213 (S. D. Ala. r93I). 
requires that the trial of all crimes shall be by jury except in cases of impeachment. The Supreme Court has, however, repeatedly upheld the rule that despite the Amendment misdemeanors not involving infamous punishment were petty offenses and might be tried without a jury if Congress so provides. It would seem to follow that a proceeding with respect to such an offense would not be a "criminal prosecution" within the meaning of the Sixth Amendment which guarantees the right of trial by jury in all criminal prosecutions. Congress by the Act of December 16, $193^{29}$ has defined petty offenses as those for which the penalty does not exceed confinement in a common jail without hard labor for a period of six months or a fine of not more than $\$ 500$ or both. Under the old Food and Drugs Act violations thereof were held to be petty offenses. ${ }^{30}$ While second offenses were subject to the possibility of punishment by imprisonment, the maximum imprisonment was not over one year. Therefore the violator could oniy be sentenced to jail and not a penitentiary, nor could the sentence be to hard labor. Admitting that Congress could deprive defendants of the right of jury trial in case of petty offenses, it did not see fit to do so under either the old Act or the new Act.

Petty Offenses and Informations. The matter of petty offenses also bears on the question whether prosecution may be instituted by indictment only or by either indictment or information. The Act of December 16, I930, not only defined petty offenses but also provided that all such offenses may be prosecuted upon information or complaint. It was at first urged that offenses not falling within the Congressional definition of petty offenses could not be prosecuted by information. Nevertheless the more drastic penalties would not seem to take the offenses out of the class of petty offenses, despite the Act of December 16 , 1930. It was frequently held that offenses under the old law could be prosecuted by information. ${ }^{31}$ This rule will apparently continue for the Supreme Court has taken the view that the provision as to prosecution by information laid down by Congress in the Act of December I6, I930, is not exclusive. It does not prevent the prosecution by information of other misdemeanors not involving infamous punishment. ${ }^{32}$

20 STAT. 1029.

${ }^{30}$ Frank v. U. S., I92 Fed. 864 (C. C. A. 6th, I9II); Huyler's v. Houston, 4 I App. D. C. 452 (1914).

aU. S. v. J. Lindsay Wells Co., I 86 Fed. 248 (W. D. Tenn. 1910); U. S. v. Wells, 225 Fed. 320 (W. D. Tenn. 1913); U. S. v. Weeks, 225 Fed. roif (S. D. N. Y. I912); U. S. v. I,950 Boxes of Macaroni, 181 Fed. 427 (N. D. Ill. 1910).

Duke v. U. S., 30r U. S. 492 (1937). Prior to the exhaustive restatement of the law by Mr. Justice Brandeis in Albrecht v. U. S., 273 U. S. I (1926), there was much confusion and diversity of practice with regard to the filing of informations. In this case the Court held that it may be accepted as settled that leave must be obtained of the court prior to the filing of the information and that before granting such leave the court must in some way satisfy itself that there is probable cause for the prosecution. Probable cause for prosecution may be shown by a verification of the information or by annexed affidavits thereto, or the United States Attorney may file an information under his oath of office, and if he does so, his official oath may be accepted as sufficient to give verity to allegations of the information. Wecks v. U. S., 216 Fed. 292 (C. C. A. 2d, 1914).

According to present practice under the Food and Drugs Act of 1906, the information is made on the oath of the United States Attorney but is also accompanied by affidavits of the Food and Drug Administration inspector and analyst who investigated the case, sworn to before a Department official. 43 Star. 803 (I925).

While affidavits are not the only meass of satisfying the court that there is probably cause for the 
Venue. Under the Constitution trial is required to be held in the state and district in which the crime is committed. The most common offense under the new Act, as under the old $\mathrm{Act}^{33}$ would be the introduction into interstate commerce of adulterated or misbranded articles. In virtually all cases, therefore, venue would be in the judicial district from which the articles are shipped.

\section{Libel for Condemnation Proceedings}

Seizure. Under the libel for condemnation proceedings ${ }^{34}$ any food, drug, device, or cosmetic that is adulterated or misbranded when introduced into or while in interstate commerce or which may not under the permit system be introduced into interstate commerce, may be proceeded against while in interstate commerce or at any time thereafter. The essential elements of the procedure are that the article may be seized pursuant to court process and condemned by the court. The new Act broadens the scope of the seizure provisions. Under the old Act the article was required to be adulterated or misbranded at the time of seizure pursuant to court process. ${ }^{35}$ Nor could the article be seized after it left interstate commerce but only so long as it was being transported in such commerce, or, having been transported therein, remained unloaded or unsold or in the original unbroken package. ${ }^{\mathbf{3 6}}$

Federal law is familiar with two types of seizures. One is seizure not pursuant to judicial process but made by an executive official (or in some cases a private individual) pursuant to search warrant where necessary, and prior to judicial proceedings. ${ }^{37}$ The other type is seizure pursuant to judicial process as under the federal food and drugs legislation. A considerable amount of confusion exists as to these two types of seizure proceedings. ${ }^{38}$

The category of executive seizures is illustrated by many provisions of the navigation, customs, and revenue laws and the former prohibition laws. These granted the courts jurisdiction to confiscate or to condemn property previously lawfully seized by executive officers. In this type of proceeding the seizure by the executive officer

prosecution, the affidavits do become necessary if a warrant of arrest is to issue pursuant to the filing of the information. The Fourth Amendment to the Constitution declares that the warrant shall issue only upon probable cause supported by oath. So also the affidavits serve as a basis for the issuance of a summons without an arrest, which is particularly the practice in prosecutions against corporations.

$\$$ The old Act also defined the crime in such manner as to permit venue also in the judicial district into which the goods were shipped. U. S. v. Alaska Consolidated Canneries, 2 F. (2d) $61_{4}$ (W. D. Wash. I924). *4 $\$ 304,2$ I U. S. C. $\$ 334$.

*U. S. v. Five Boxes of Asafoetida, I8I Fed. 56r (E. D. Pa. Igro) holding that article, although misbranded in interstate commerce, may not be seized if labeling corrected prior to seizure.

20 II0, 2 I U. S. C. \$I4.

"See, e.g., The Brig Ann, 9 Cranch 289 (U. S. 1815); The Josefa Segunda, ro Wheat. $3 \times 2$ (U. S. 1825); Clifton v. U. S., 4 How. 242 (U. S. 1846); U. S. v. Lariviere, 93 U. S. 188 (1876); U. S. v. Winchester, 99 U. S. 372 (1878); Coffey v. U. S., I16 U. S. 436 (I886).

${ }_{33}$ This confusion is well illustrated by the following two cases: Daeufer-Lieberman Brewing Co. v. U. S., 8 F. (2d) I (C. C. A. 3rd, I925) and U. S. v. 8 Packages or Casks of Drugs, Not. Judg., Food \& Drugs, No. 697 (D. C. Ohio 1910). Contra to the first of these cases are U. S. v. 2615 Barrels of Beer, I F. (2d) 500 (M. D. Pa. I924) and Quandt Brewing Co., Inc. v. U. S., 47 F. (2d) I99 (C. C. A. 2d, 1931). Contra to the second case are U. S. v. George Spraul \& Co., I85 Fed. 405 (C. C. A. 6th, I9Ir); U. S. v. 2 Barrels of Dessicated Eggs, 185 Fed. 302 (D. Minn. I9II); U. S. v. roo Barrels of Vinegar, I 88 Fed. 47 I (D. Minn. I9II); and U. S. v. Capon Water Co., 30 F. (2d) 300 (E. D. Pa. I929). 
is a necessary prerequisite to court jurisdiction of the confiscation or condemnation proceedings.

In the case of libel for condemnation proceedings under the food and drugs legislation the seizure is not a jurisdictional element of the cause. Jurisdiction is acquired by the court through the filing of the libel in accordance with the usual admiralty practice. Thereupon judicial process issues for attachment or seizure of the res. By such seizure pursuant to court process control is obtained over the res but such control is not a prerequisite to the institution of the libel for condemnation proceeding. ${ }^{39}$

Case at Law and Extent of Admiralty Practice. Similar to the old Act, the new Act provides that the procedure in libel for condemnation cases shall conform "as nearly as may be" to the procedure in admiralty except that on demand of either party any issue of fact joined in any such case shall be tried by jury. This requirement does not give to the federal courts jurisdiction in admiralty in libel for condemnation proceedings. It is only when a seizure is made on the high seas or navigable waters of the United States that proceedings for forfeiture present a cause for admiralty or maritime jurisdiction under the general maritime law. ${ }^{10}$ In no case does a seizure on land present a case cognizable in admiralty. ${ }^{11}$ Inasmuch as the enforcement of forfeiture against articles seized on land does not present a case cognizable in admiralty but a civil suit at common law ${ }^{42}$ a jury trial can not be dispensed with as in admiralty but must be preserved in accordance with the Seventh Amendment to the Constitution. 13

The question arises as to the extent to which the procedure in the law case is to conform to admiralty as a result of the statutory requirement that it shall conform "as nearly as may be." This question was settled in part by the Supreme Court in the case of 443 Cans of Frozen Egg Products v. United States. ${ }^{44}$ The admiralty procedure requirement was there interpreted as extending to the seizure of the property by process in rem while the appellate review is not by appeal with trial de novo as in admiralty but by writ of error as at law. The case implies but does not decide that the nature of the proceedings subsequent to the seizure and prior to review of the final court order is as at law.

In practice, however, the filing of the libel, the seizure, the intervention of the claimant, his answer, and all other pleadings until the case is at issue are in accordance with admiralty practice. On the other hand, the trial itself is conducted as an

-U. S. v. Capon Water Co, supre note 38.

"InVengeance, 3 Dall. 297 (U. S. 1796); The Schooner Sally, 2 Cranch 406 (U. S. 1805); The Betseg and Charlotte, 4 Cranch 443 (U. S. 1808).

a The Sarah, 8 Wheat $39 x$ (U. S. 2823 ); U. S. v. Winchester, 99 U. S. 372 (1878); Union Insurance Co. v. U. S., 6 Wall. 759 (U. S. 1867); Morris' Cotton, 8 Wall. 507 (U. S. 1869).

- 443 Cans of Frozen Egg Products v. U. S., 226 U. S. 172 (1912). See to same effect, Lerington Mill and Elevator Co. v. U. S, 220 Fed. $6 \times 5$ (C. C. A. 8th, r913); affirmod on other grounds, 232 U. S. 399 (I914); U. S. v. 10 Cases, etc, Bred Spred, 49 F. (2d) 87 (C. C. A. 8th, 1931).

The Sarah, 8 Wheat. 391 (U. S. 1823); U. S. v. 130 Barrels of Whiskey, 27 Fed. Cas. No. 15938 (S. D. Ohio 1865); The Queen, 27 Fed. Cas. No. 16107 and 16108 (S. D. N. Y. 1870); The J. W. Freach, 13 Fed. 916 (E. D. V2. 1882 ).

4 226 U. S. 172 (I9I2). 
ordinary trial at law and the rules of evidence governing such trials are applied, but the judgment is a decree in the form of an admiralty decree. In accordance with the Supreme Court decision appellate proceedings are as in law cases. Thus, even if the case is tried without a jury, the review is as in cases at law limited to the consideration of questions of law presented by the record proper independent of special findings of fact by the trial court.

The Libel and Process. The libel is one of information filed in the office of the clerk of the United States District Court for the judicial district in which the article is found. It need not be supported by oath. Process is issued by the clerk of the court to the marshal as a matter of course upon filing of the libel. The suit being by the United States no stipulation for costs is a prerequisite. ${ }^{45}$ The process is a warrant of attachment of the property and a monition to all persons interested to appear on a day certain to show cause why the property should not be condemned:

Release Under Bond. In the usual admiralty proceeding, the property attached may by court order, even before return of process, be released under bond to the claimant, upon a money deposit or stipulation with sureties in an amount fixed by the court. However, libel for condemnation proceedings are not proceedings resulting in a money judgment, but in the condemnation of particular articles. If an article were proceeded against, for instance, because it is adulterated in that it contains an added poisonous ingredient, and then were released under bond before trial and without correction of its adulterated character, its subsequent disposition, while leaving a remedy on the bond to the government by way of a money judgment, would result in purchasers' obtaining an article which would be fatal or harmful to their health. In consequence, there is usually no interlocutory release under bond of the article attached. ${ }^{46}$

Claimant. Any person having an interest in the property attached may make claim thereto by filing notice of appearance prior to the return day together with a stipulation for costs. If no appearance is made the government may obtain a decree of condemnation on proof of actual notice to owners of the goods attached or the person in possession of the goods at the time of attachment and after proof in addition of the required publication.

Decree and Disposition of Articles. In the event that the condemnation of the article is decreed, the court may, in its discretion, order the article to be disposed of

\footnotetext{
" Costs and Storage Charges.-Prior to the new Act the Supreme Court seemed to regard the matter of assessing costs and expenses against intervening claimants as governed by admiralty principles. Hipolite Egg Co. v. U. S., 220 U. S. 45 (IgI'). But cf. U. S. v. I590 Cases of Tomato Pulp, 255 Fed. 228 (E. D. $\mathrm{Pa}$. 19r9). The new Act, however, specifically provides that when a decree of condemnation is rendered against an article, court costs and fees and storage and other proper expenses shall be awarded against the person, if any, intervening as claimant of the article This new provision settles many uncertainties that previously existed as to payment of costs and storage expenses.

Claimont's costs in libel for condemnation proceedings can not be adjudged against the United States even if the claimant wins. Charles v. U. S., I83 Fed. 566 (C. C. A. 5th, I9I0); and U. S. v. French Sardine Co., 80 F. (2d) 325 (C. C. A. 9th, 1935).

${ }^{\prime \prime} \mathrm{Cf}$. the unusual circumstances of U. S. v. 408 Bushels of Oysters in the Shell, Not. Judg., Food \& Drugs, No. 4922 (D. N. Y. 1915).
} 
by government officers by destruction or sale, or by release to the owner on bond for destruction or sale after being brought into compliance with the Act through relabeling or reconditioning. ${ }^{47}$ No sale of a condemned article may be made if the sale would be in violation of the new Act or the laws of the state in which sold. The disposition made by the owner of the article must be under the supervision of an officer or employee designated by the Secretary of Agriculture and the expenses of such supervision are to be paid by the owner. Under the old law the Food and Drug Administration has usually opposed any release to the owner for reconditioning and sale if the case is one of adulteration that in the Administration's judgment cannot be corrected by relabeling or reconditioning as, for example, poisonous or decomposed foods. ${ }^{48}$ If following release to the owner, the article is disposed of in violation of the conditions of the bond, the bond may be forfeited or the owner punished for contempt of the court order. ${ }^{40}$

Multiple Seizures. The most extensive changes made by the new Act in the libel for condemnation proceedings are those relating to multiple seizures. Multiple seizures present the question whether the government may libel for condemnation a particular lot when seizure proceedings on a different lot of the same product are still pending. There is always the possibility of undue hardship on the manufacturer if he is compelled to defend numerous libel proceedings at the same time in numerous district courts over the country. Thus in the $B$. $\mathcal{E} M$. External Remedy Case where twelve such proceedings were pending simultaneously in widely separated district courts, the Court of Appeals for the District of Columbia stated that such prosecutions were unnecessarily oppressive. ${ }^{50}$

The new Act proposes to meet the multiple seizure situation by providing that no libel for condemnation proceeding may be instituted for misbranding if another such proceeding is pending in any court based upon the same alleged misbranding, and that not more than one such proceeding shall be instituted if no other such proceeding is so pending. The limitation'does not apply to adulteration cases, and further there are broad exceptions that permit multiple seizures if the alleged misbranding has been the basis of a prior judgment in favor of the United States in any criminal, injunction, or libel for condemnation proceeding, or if the Secretary of Agriculture has probable cause to believe from the facts found, without hearing,

"In cases of default condemnation decrees where no claimant appears, the court has occasionally ordered the distribution of the articles to some charitable institution if the articles are of value and contain no injurious ingredients, or has turned them over to the Department of Agriculture for experimental purposes.

${ }^{a}$ Occasionally the court has refused to release to the owner on bond under other circumstances, as, for instance, where the article was fraudulently misbranded to represent competing articles of much higher value to the injury of trade competitors and the claimant has been convicted of similar offenses before and had numerous other proceedings pending against him. U. S. v. Two Cans of Sweet Birch and Three Cans of Oil of Gaultheria, 268 Fed. 866 (S. D. N. Y. 1920). For release under bond contrary to the Adminis, tration's representations, see U. S. v. I443 Cases, etc., Canned Salmon, 7 F. Supp. 77 (W. D. Wash. í934).

"Sec, e.g., U. S. v. 40 Barrels of Adulterated and Misbranded Buttermilk, Not. Judg., Food \& Drugs, No. 17,275 (D. Ore. 1930).

${ }^{50}$ National Remedy Co. v. Hyde, 50 F. (2d) 1066 (App. D. C. 1931). See also, Hearings before the Senate Committee on Agriculture and Forestry on S. 4235, 69th Cong., Ist Sess. (1926) 3. 
that the misbranded article is dangerous to health, or that the labeling is fraudulent, or that the labeling would in a material respect mislead to the injury or damage of the purchaser or consumer.

Provision is also made that in situations where the number of libel for condemnation proceedings is limited, the one proceeding instituted may be removed for trial to any district court agreed upon by stipulation between the parties, or in the absence of such a stipulation to a district court of reasonable proximity to the claimant's principal place of business. Further, in situations where multiple seizures are permitted, proceedings pending in two or more jurisdictions are required on application by the claimant to be consolidated for trial. The trial may be had in any one of the districts where proceedings are pending, to be selected by the claimant, or in a district agreed upon by stipulation between the parties, or if neither of these alternatives is adopted, in a district court of reasonable proximity to the claimant's principal place of business.

Res Judicata. A further problem arises if the government libels a particular lot of a product, when with respect to a different lot of the same product, the claimant has either been acquitted in previous criminal proceedings or a decree unfavorable to the government has been entered in previous libel for condemnation proceedings. The problem is one as to what constitutes res judicata under the food and drug legislation.

One of the earliest series of cases typical of this point arose under the Insecticide Act which contains libel for condemnation provisions similar to those for food and drugs. In 1917 the government filed a criminal information in the United States District Court of Nebraska charging the George H. Lee Co., with misbranding a number of cans of insecticide. The court instructed the jury that the government must prove that the violation was fraudulent or intentional. The jury then returned a verdict of not guilty. ${ }^{51}$ The instructions of the court were clearly in error, yet no appeal would lie because the case was a criminal one. In 1927 the government filed a libel for condemnation in a United States District Court for Missouri ${ }^{52}$ against a number of cans of the same insecticide charging that the articles were misbranded. The George H. Lee Company appeared as claimant and set up in its answer the judgment in the Nebraska case as a bar. The motion of the government to strike out this portion of the answer was granted. However, when the case was tried it resulted in a decree in favor of the claimant.

Subsequently, in 1928 , the government instituted libel for condemnation proceedings against another consignment of the same insecticide in a United States District Court in California. ${ }^{53}$ The same defense was presented by the claimant who offered in evidence not only the judgment in the Nebraska case but also the decree in the Missouri case. The court excluded this evidence on the objection of the government

U. S. v. George H. Lee Co., Not. Judg., Insecticides, No. 1052 (D. Nebr. 1924).

${ }^{20}$ U. S. v. 63 Quarts of Lice Killer, Not. Judg., Insecticides, No. 1191 (W. D. Mo. 1928).

$\approx$ U. S. v. 65-3/12 Dozen Quart Size Lee's Lice Killer, Not. Judg., Insecticides, No. 1192 (S. D. Calif. 1930). 
to its admissibility, and entered the order finding for the government on the misbranding charges. On appeal, however, the Circuit Court of Appeals for the Ninth Circuit reversed the judgment of the lower court, holding that the government was estopped by the judgment and decree in the earlier Nebraska and Missouri cases..$^{64}$ The only difference between the present case and the earlier cases, according to the court, was that different shipments were involved. This was not sufficient to prevent the application of the principle of res judicata. ${ }^{55}$

If the doctrine of res judicata is applied, the result is that a final decision by any court adverse to the government's contentions would give the manufacturer of a particular article the privilege of doing an interstate business in that article free from molestation thereafter by the government. It means that the government could not afford to lose a single case brought against an article of food or drugs. It would result in a substantial increase in the contested cases because manufacturers could afford to contest many actions brought against their goods in the hope that one of them would return a favorable verdict.

The question also arises as to whether the claimant would be estopped after a decree of condemnation in favor of the government from asserting in the future that his goods were not misbranded, and whether all that the government would need to show in subsequent libel actions would be the prior judgment.

Food and drug cases are often presented to courts not fully informed as to the nature of the Act and equally as often presented by inexperienced assistants to district attorneys. Also, the inconsistencies in jury verdicts are notorious. Further, formulas and therapeutic claims for drugs, for instance, vary from year to year for different lots of drugs marketed under the same brand name or trademark. A mere change in prevailing medical opinion would often cause valid therapeutic claims to become invalid or conversely. There are bound to be variations in any two cases between the evidence presented and the manner of presentation. These are practical considerations that indicate that the doctrine of res judicata should not be applicable.

\footnotetext{
${ }^{4}$ George H. Lee Co. v. U. S., 41 F. (2d) 460 (C. C. A. 9th, 1930).

"For similar series of cases, see "Lee's Save the Baby":-U. S. v. Certain Bottles of "Lec's Save the Baby," 37 F. (2d) 137 (D. Conn. 1929). "Bred Spred": U. S. v. 49-1/2 Cases of Bred Spred, Not. Judg., Food \& Drugs, No. I735I (E. D. Mich. 1927); U. S. v. I5 Cases of Bred Spred, Raspberry Flavor, Not. Judg., Food \& Drugs, No. 17352 (D. Ind. 1928); U. S. v. Io Cases of B̈red Spred, Not. Judg., Food \& Drugs, No. 18426 (S. D. Iowa I930); U. S. v. Io Cases More or Less of Bred Spred, 49 F. (2d) 87 (C. C. A. 8th, I931). B. \& M. External Remedy: U. S. v. I I Packages of B. \& M. External Remedy, Not. Judg., Food \& Drugs, No. 1 r67x (D. N. H. 1923); U. S. v. 8 Dozen Bottles B. \& M. External Remedy, Not. Judg., Food \& Drugs, No. I8176 (various District Courts, 1929-3I); National Remedy Co. v. Hyde, Not. Judg., Food \& Drugs, No. 16780 (Sup. Ct. D. C. 1929), National Remedy Co. v. Hyde, 50 F. (2d) Io66 (App. D. C. I93I).

For decision by the Supreme Court involving similar problems in a customs case, see U. S. v. Stone and Downer Co., 274 U. S. 225 (1927), holding that the doctrine of res judicata is not applicable in the matter of classification of importations of similar articles; but see Coffee v. U. S., II6 U. S. 436 (I886); Stone v. U. S., 167 U. S. 178 (1897); Murphy v. U. S., 272 U. S. 630 (1926); Aycock v. O'Brien, 28 F. (2d) 8 I7 (C. C. A. 9 th, 1928).

As to cases on estoppel on prior judgment, see Cromwell v. County of Sac, 94 U. S. 351 (1876); Bissell v. Spring Valley Township, 124 U. S. 225 (1888); New Orleans v. Citizens Bank, 167 U. S. 371 (1897); Southern Pacific R. R. Co. v. U. S., I68 U. S. I (1897); Dennison v. U. S., 168 U. S. 241 (1897).
} 


\section{Injunction Enforcement Proceedings}

A wholly novel enforcement procedure, so far as federal food and drug legislation is concerned, is provided by the new Act. This is the injunction procedure. ${ }^{56}$ Under it a statutory injunction may be obtained to restrain the principal offenses under the Act and certain of the minor ones as heretofore mentioned.57

The objectives sought by Congress in providing for the new procedure are stated in the report of the House Committee on Interstate and Foreign Commerce:

This procedure will be particularly advantageous in border-line cases that cannot be settled without litigation. In many such cases it is unfair to the manufacturer to subject him to criminal trial and likewise unfair to the public to have the issue determined under the restrictions necessarily prevailing in criminal procedure. This remedy should reduce litigation. In some cases it should avoid the hardship and expense to litigants in seizure cases. In many instances seizure is a harsh remedy and should be discouraged or confined to those cases where the public protection requires such action. In many cases, it is believed ... injunctions can be used with equal effectiveness and with less hardship. A seizure case finally decided in favor of a defendant leaves him without recourse for his losses, including court costs, storage, and other charges. ${ }^{58}$

There is no statutory provision for a jury trial as a part of the injunction proceeding. However, if the injunction is violated the new Act specifically provides that on demand of the accused a jury trial may be had in the subsequent contempt proceedings. The constitutional validity of a statute that, though permitting the government to substitute injunction for criminal proceedings, deprives an individual of a jury trial with respect to an offense for which a jury trial had theretofore been available, is not wholly clear. The injunction proceedings authorized are analogous to the common law right of the state to abate and restrain public nuisances through injunction. This public nuisance category has been extended by legislation authorizing injunction enforcement proceedings for vazious minor offenses in health and similar fields without a jury trial being necessary. ${ }^{59}$ Violations of the Food, Drug, and Cosmetic Act would seem likely to fall within this category. This is particularly so since offenses under the Act for the most part can be regarded as petty offenses for which Congress could even in criminal proceedings, if it chose, deprive the defendant of a jury trial. That there are limits beyond which Congress may not go in providing for law enforcement by injunction seems obvious, but the scope to be given to the constitutional guaranty of a jury trial still remains to be defined..$^{\text {Bo }}$

\section{Exclusion of IMPORT Proceedings}

The new Act makes no extensive changes in the exclusion of imports proceedings. The proceedings are wholly administrative and involve no court action although

$\$ 302,2 x$ U. S. C. $\$ 332$.

ot The granting of temporary restraining orders without notice and the practice and procedure in case of contempt proceedings are governed by $\$ \$ 17$ and 22 of the Clayton Act, 38 STAT. 737 (19I4), 28 U. S. C. $\$ 38 \mathrm{I}$, which are incorporated by reference into the new Act.

${ }^{8}$ H. R. REP. 2139, 75th Cong., 3d Sess. (1938) 3-4.

${ }^{50}$ See Statutory Extension of Injunction Law Enforcement, Note (1932) 45 Harv. L. Rev. rog6. In recent years the statutory injunction proceedings have also been extensively used by Congress for enforcement of administrative orders in quasi-judicial proceedings without providing for a jury trial.

${ }^{\infty}$ See Simpson, Fifty Years of American Equity (1936) 50 Harv. L. REv. 224-227. 
judicial review is possible in collateral injunction proceedings against the appropriate government official ${ }^{61}$ or in a collateral suit by the government on the importer's bond. The exclusion proceedings require the complementary action of two departments of the government, the Department of Agriculture and the Treasury Department. Under the exclusion of import proceedings, articles offered for importation are refused admission if manufactured or processed under unsanitary conditions, or if forbidden or restricted in sale in the country in which produced' or from which imported, or if the article is adulterated or misbranded, or is a new drug and no application for its use has become effective.

Pending determination of the admissibility of an article, it may be released to the importer under an "entry bond" for the full invoice value of the goods plus the duty thereon, conditioned on the article's conformity to the requirements of the law and the return of the shipment to customs custody if demanded. Unless, upon the investigation of samples of the shipment, a violation is disclosed, a notice of release is sent to the importer. ${ }^{62}$ Where violation is found, notice is given and an informal hearing held. If the decision is adverse to the importer, he may appeal-again informally-first to the Chief of the Food and Drug Administration and then to the Secretary of Agriculture. ${ }^{63}$ If the appeal is denied, the shipment is destroyed unless exported within three months or unless it is released for reconditioning under a procedure similar to that used in libel for condemnation cases. If the shipment is not disposed of by one of these methods, action may be brought on the importer's bond. To avoid forfeiture of the full amount of the bond, such suits are frequently compromised.

The procedure described above has not been materially altered under the new Act. ${ }^{64}$

Embargoes. The old Act provided for refusal of admission not only if the article was adulterated or misbranded but also if it was otherwise dangerous to the health

${ }^{1}$ Ambruster v. Mellon, 4I F. (2d) 430 (App. D. C. 1930). See, for a legislative investigation of the situation surrounding this case, Administration of the Food and Drugs Act, Hearings before the Senate Committee on Agriculture and Forestry, 71st Cong., 2d Sess. (Feb. I2 to June 30, 1930). Usually the injunction is sought to restrain the government officer from applying an unreasonable standard or test in ascertaining whether the article is in violation of the applicable Act and from further holding the shipment in customs custody. See Knapp v. Calloway, 52 F. (2d) 476 (S. D. N. Y. 1931) and Knapp v. Hyde, 50 F. (2d) 272 (S. D. N. Y. I93I). For successful proceedings under the similar exclusion of import proceedings of the Tea Import Act, see Waite v. Macy, 246 U. S. 606 (19r8). Cf. Buttficld v. Stranahan, I92 U. S. 470 (rg04), and Sang Lung v. Jackson, 85 Fed. 502 (C. C. N. D. Cal. I898).

Releases are of three types: a straight "release without comment" which may be considered by the importer as a definite determination that future shipments of the same character will not be detained; a "release without prejudice" if there is doubt as to whether a violation of law is involved but further proceedings are not desired to be instituted, such release indicating that future shipments may be detained on the basis of further information and subsequent examination; and a "release with warning" which is issued in those cases in which the article is in violation of law but, by reason of the newness of the applicable standard or regulation, it seems fair to give warning to the trade before detaining and excluding from admission shipments offered for importation.

Appeals to the Secretary are rare and are usually, but not always, referred by him to the Chief of the Food and Drug Administration.

"In the new Act the "entry bond" is described as a "bond as liquidated damages" instead of as a "penal bond." It is doubted that this will affect the present practice of compromising suits on these bonds. 
of the people of the United States. This health provision in the old law was used as a basis for certain embargoes imposed by the Food and Drug Administration. Under these any article of the class embargoed was automatically excluded from importation following a declaration of embargo by the Secretary of Agriculture. This health provision has been omitted in the new Act although seemingly the definition of adulteration under the new Act is sufficiently broad to cover any situation in which the article has in it any substance, whether or not added, in sufficient quantity to render the article injurious to health.

The embargo has been used even though seemingly the provisions of the old Act contemplate refusal of admission only following examination of a particular lot offered for importation, opportunity for hearing to the importer or owner, and findings by the food and drug officials pursuant to the ordinary exclusion procedure. For example, in 1927 a typhoid outbreak occurred in and near Montreal, Canada. More than 1,000 cases were reported within a short time. Substantial amounts of milk and cream from this area were customarily imported into the United States. The Secretary therefore ordered an embargo against milk and cream originating within this area until such time as the source of the infection was definitely determined and authorities of this government were satisfied that adequate preventative measures had been taken. ${ }^{65}$

No court contest has ever arisen as to the validity of the several embargoes, probably since the dangerous character of the articles embargoed was not seriously questioned. ${ }^{68}$

\section{Factory Inspection and Permit Proceedings}

Factory Inspection. Without specific authority of law, except in the case of seafood, the Food and Drug Administration has maintained under the old Act a voluntary system of inspection of factories in which are manufactured food and drugs for interstate shipment. Most manufacturers do not object to inspection of their factories, although their acquiescent attitude may be induced in part by the same considerations mentioned earlier that lead them to furnish "voluntary" samples. Reports of factory inspections present valuable information as to the likelihood of violations of the Act occurring with respect to the product of the particular manufacturer in the event the articles are shipped in interstate commerce. The reports also enable the Administration to plan its enforcement projects. Factory inspection further enables the detection of many forms of violation that would be difficult of ascertainment without such inspection. This is particularly true of foods produced under unsanitary conditions. In many instances it is impossible to determine from a chemical

\footnotetext{
${ }^{\infty}$ Press Release, Dep't Agr., March 28, 1927. This matter could now be dealt with under the later Milk Import Act, supra note 3 .

For other examples of embargo, see absinthe: Food and Drug Inspection No. 147, July 25, I9r2; peyote: S. R. A., Chemistry, No. 13, May 3, 1915, p. 3; cannabis sativa: S. R. A., Chemistry, No. I6, Jan. 26, 1916, p. 30; beans from India or East Indian colonies: S. R. A., Chemistry, No. 20, July 2, 1917, p. 62 .

"some of the embargoes perhaps could have been established by action of the President pursuant to the Act of August 30, 1890, 26 STAT. 415, $\$ 4,21$ U. S. C. $\$ 18$. However, this procedure was not used.
} 
or bacteriological examination the conditions under which a particular food or drug was produced. Specific authority for such factoiy inspection is written into the new Act. ${ }^{67}$ The inspecting official must make request of the owner, and the entry and inspection requested must be undertaken at a reasonable time. Refusal to permit such inspection subjects the owner to a penalty.

Voluntary Seafood Inspection. Under the Meat Inspection Act a similar factory inspection system, but one including compulsory observance of requirements as to sanitary conditions for the processing of products for interstate shipment, has been authorized by law for meat packing plants since I906. This Act served as a legislative precedent for writing into the old Food and Drugs Act the amendment of I934 providing for an inspection system covering seafood. ${ }^{88}$ This inspection system is in effect a permit system for seafood processors. It is one of the few provisions of the old Act that is not repealed but is continued in force for the future by the new Act. ${ }^{68}$

Investigations by the Food and Drug Administration of shipments of seafood showed that excessive amounts of seafood, particularly shrimp, were filthy, decomposed, or otherwise unfit for food. Numerous libel for condemnation and criminal proceedings were instituted and had an injurious effect on the market. In consequence, the industry itself supported a different approach to the problem and urged the seafood amendment. The difficulties lay in the inability of the packer to compel the fishermen to adopt proper practices and in the under-processing, lack of equipment, and lack of packing personnel adequately trained and supervised to exclude shrimp not fit for food.

Pursuant to the amendment, the inspection system was first inaugurated for shrimp packing plants. It is voluntary although a number of inducements are embodied in the amendment and the regulations thereunder to make acceptance of the system widespread. A packer may apply for inspection for his plant and is granted it if the plant possesses suitable specified processing equipment and sanitary facilities. In order to retain the inspection service the packer must also observe sanitary requirements as to unloading platforms, equipment and plant, and prevention of bacterial spoilage, processes specified for closure of the can, and requirements as to the time and temperature for processing. A plant for which inspection is being furnished may not can, handle, or store shrimp that has not been inspected and approved by the food and drug inspectors. The plant is required to dispose of, for non-food purposes, shrimp condemned by them as unfit for food. The cost of the service is paid.by the owner of the plant and amounts to about one-fourth of a cent per can. Lots of canned shrimp inspected and passed as conforming to the requirements of the regulations are issued an inspection certificate to that effect, and the labels thereon are required to bear the legend "Production Supervised by United States Food and Drug Administration."

\footnotetext{
${ }^{7} \$ 704,21$ U. S. C. 374 .

48 Stat. 1204 (I934), am'd, 49 STAT. 87 I (1935), 2 I U. S. C. $\$ 372 a$.

$\infty$ \$902(a), 21 U. S. C. $\$ 392(2)$.
} 
The inspection system is also interwoven with a label approval system. Not only must the labels bear certain prescribed statements, but they also are required to be submitted to the Food and Drug Administration for approval. Approval will be given only if the label is found to conform to the requirements of the Food and Drugs Act as to misbranding and the like. While there is no direct prohibition against the use of an unapproved label, failure to submit labels for approval is a basis for withdrawal of inspection. The use of an unapproved label is also a basis for denying an inspection certificate. Practically, only approved labels are used. An approved label may not be used on canned shrimp that has not been inspected unless destined for export.

While the shrimp inspection service is not a mandatory requirement of law, practically its use for the shrimp packer has been found advantageous. Unless the packer avails himself of the inspection service, his product, if shipped in interstate commerce, is liable to condemnation if found to be unfit for food and the packer is subject to criminal prosecution. Use of the inspection certificate avoids the likelihood of such proceedings and the trade losses that result from the attendant publicity. Also, unless the packer avails himself of the inspection service he is unable to label his products under the supervision of the government, and as a result sales resistance is met both from distributors and consumers.

It is contemplated that similar inspection service will be established for salmon and other seafood, although at a hearing in 1936 spokesmen representing $92 \%$ of the salmon canning industry refused to request inspection.

Compulsory Emergency Permit Control. The new Act ${ }^{70}$ adds a further inspection and permit system that has no voluntary aspects. It is applicable to any class of food that the Secretary finds injurious to health by reason of contamination of micro-organisms during manufacturing, processing or packing thereof in any locality, provided the Secretary also finds that the injurious nature of such class of food cannot adequately be determined after the articles have entered interstate commerce. Such a system would also cover seafood and presumably be applicable to the salmon industry which has not acquiesced in the voluntary system under the seafood amendment. It would also, of course, apply to many other classes of foods subject to unsanitary conditions in connection with their preparation.

Following any such finding of the Secretary, manufacturers, processors, or packers of such class of food are required to obtain permits to which are attached conditions governing the manufacturing, processing, or packing methods. The system is regarded as a form of emergency control and the permits are required under the Act only for such temporary periods as may be necessary to protect the public health. However, the Act does not mention any specific time limit. While the permit system is in effect no person may introduce or deliver for introduction in interstate commerce any class of food covered by the system unless he has in effect a permit. Permits may be suspended by the Secretary immediately if any of the conditions

\footnotetext{
${ }^{70} \$ 404,2$ I U. S. C. $\$ 344$.
} 
thereof have been violated. No preliminary hearing is required in view of the necessity for prompt action, but the holder may apply for reinstatement and a prompt hearing on his application therefor. If inspection shows that adequate measures have been taken to comply with and maintain the conditions of the permit, it is required to be reinstated. Employees of the Food and Drug Administration duly designated for the purpose may have access to the factory at all times in order to ascertain whether or not the conditions of the permit are being complied with and denial of such access is a ground for suspension of the permit. The compulsory inspection system under the Meat Inspection Act is closely similar and is apparently constitutionally valid. ${ }^{71}$

\section{PUBLICITX}

Notices of Judgment. The new Act provides that the Secretary of Agriculture shall cause to be published from time to time reports summarizing all judgments, decrees, and court orders rendered under the Act, including the nature of the charge and the disposition thereof. ${ }^{72}$ This is similar to the provision of the old Act providing for the publication of the so-called notices of judgment. The main purpose served is that of an additional deterrent to violations of the Act, for in general it may be said that the publicity resulting from the notices of judgment is frequently superior in its deterrent effect to that of the penalties imposed. This follows because public knowledge that the product has been involved in a violation of the law serves to prejudice it in the eyes of wholesalers and retailers and to some extent the consumers, and the data contained in the notices of judgment are doubtless made use of by trade competitors. The validity of the authority granted the Secretary to issue notices of judgments has never been seriously contested. ${ }^{73}$

Public Warnings. The new Act also provides ${ }^{74}$ for the dissemination of information regarding food, drugs, devices or cosmetics in situations involving, in the opinion of the Secretary, imminent danger to health or gross deception to consumer. This authority will permit keeping the public and the trade advised of the results of investigations made by the Department of particular classes of articles. The provision also gives specific statutory authority for the educational and cooperative work that the Department has engaged in in the past through public warnings in the form of press releases. These usually cover types of violations that come to the Food and Drug Administration's attention and that it expects the trade to correct, or in regard to which it desires to warn the public for its own protection.

Publicity is an effective part of the administrative machinery of the Food and Drug Administration and makes it practicable to reduce litigation and use the more drastic enforcement procedures only for the more flagrant types of violations.

7 Pitsburgh Meling Co. v. Totten, 248 U. S. 18 (1918); U. S. v. Cudahy Packing Co., 243 Fed. 44r, 450 (D. Conn. 1917).

\$705(a), 21 U. S. C. $\$ 375$ (a).

${ }^{73}$ Cf. Huyler's v. Houston, 4I App. D. C. 452 (1914); Arbuckle v. Blackburn, 113 Fed. 616 (C. C. A. 6th, 1902).

76 $\$ 705(b), \$ 375(b)$. 